\title{
SUNDHEDSPLEJE, BØRNEHAVE OG KONKURRENCESTAT?
}

\author{
OLINE PEDERSEN
}

Har sundhedspleje, børnehaver og konkurrencestat noget med hinanden at gøre? Det spørgsmål vil være omdrejningspunktet for denne artikel. Konkurrencestaten er et teoretisk begreb, som især Ove Kaj Pedersen i en dansk sammenhæng har anvendt til kritisk analyse af den transformation, som han mener, at velfærdsstaterne er i færd med at gennemgå. Det overordnede spørgsmål er, om denne transformation slår igennem som forandringer i praksis. Det arbejde, som velfærdsstatens frontpersonale udfører, er præget af kontinuitet: Dag ud og dag ind plejes gamle på plejehjemmene, lånere betjenes på bibliotekerne, børn passes $\mathrm{i}$ daginstitutionerne, sår renses, bækkener tømmes, og blodprøver bliver taget på sygehusene. Spørgsmålet er, hvorvidt, og i så fald hvordan, konkurrencestaten viser sig i denne praksis.

Her i artiklen er det de alleryngste borgere, der er i fokus. Det er dem, der netop er blevet født, og som modtager sundhedspleje, og det er dem, der er blevet så store, at de er begyndt at gå i vuggestue og børnehave. De 0-6-årige er interessante i en konkurrencestatslig sammenhæng, fordi de på den ene side er så små, at de virker fjerne fra konkurrencen mellem stater, men på den anden side er de jo statens råstof. Det er dem, vi i fremtiden skal leve af, og dem, der skal sikre landet i den internationale konkurrence. Er det mon noget, de mærker til, når de møder velfærdsstatens frontpersonale i form af sundhedsplejersker og pædagoger? Med andre ord: Hvis konkurrencestaten er en realitet, hvilke krav stiller den da til disse børn? Det er artiklens hovedspørgsmål.

For at kunne vurdere, om der findes konkurrencestatslige træk i praksis, kræves et teoretisk greb at indfange dette med. Det overordnede blik på magt og individ leveres af Michel Foucault (Foucault 2008), hvilket suppleres af Nikolas Roses videreudvikling af governmentalitybegrebet (Rose 1999). Ove Kaj Pedersen bidrager med begrebet om konkurrencestaten (Pedersen 2011) og Svend Brinkmann med de menneskelige og psykologiske implikationer af denne (Brinkmann 2008b). 
Inden dette teoretiske blik udfoldes, præsenteres den anvendte metode og indsamlede empiri. Efter teorien følger analysen, som følges op af en konklusion, hvori det diskuteres, i hvilket omfang konkurrencestatens krav viser sig over for vores yngste medborgere, og hvorvidt konkurrencestatsbegrebet på den baggrund kan siges at være analytisk relevant.

\section{Metode og empiri: at indfange praksis}

Empirien til denne artikel stammer fra to forskellige forskningsprojekter: min ph.d.- afhandling om sundhedsplejen (Pedersen 2015) samt et igangværende forskningsprojekt, hvor jeg laver feltarbejde i daginstitutioner. ${ }^{1}$ Til sammen giver de to empiriske felter mulighed for at undersøge vores samtids velfærdsstatslige tiltag over for de 0-6-årige børn.

Det empiriske materiale fra afhandlingen består af en kombination af interviews med sundhedsplejersker, fokusgruppeinterviews med mødregrupper og feltarbejde, hvor jeg var med sundhedsplejerskerne på hjemmebesøg hos borgerne, i konsultationen og deltog i deres teammøder. Feltarbejdet udgjorde den største del af empirien. ${ }^{2}$

Det empiriske materiale fra daginstitutionerne består af feltarbejde i to forskellige institutioner: I den ene var jeg på besøg i to uger, og i den anden var jeg en enkelt uge. Begge institutioner havde både vuggestuebørn og børnehavebørn. ${ }^{3}$ Mit fokus var på opfattelsen af ,det gode barn“, hvilke handlinger, ytringer og attituder der fremmes, og hvilke der sanktioneres som værende upassende eller problematiske. Samtidig var jeg særligt interesseret i „Fri for Mobberi“ ${ }^{4}$ som er et program, man $i$ varierende omfang benyttede $i$ institutionerne til oplæring af sociale kompetencer og konfliktløsning.

\section{Konkurrencestat: selv, potentialer og arbejdsmarked}

Artiklens overordnede blik på magt og individ tager afsæt i Michel Foucaults teoridannelse, idet man med dette begrebsapparat får et egnet blik på styring og disciplinering af moderne individer; et begrebsapparat, der går godt i spænd med konkurrencestatsbegrebet, fordi formning af individerne i konkurrencestaten ikke kun er tydelig og direkte, men derimod ofte subtil og indirekte. Her følger en kort introduktion til Foucaults begreber om først magt, subjektivitet, diskurs og dernæst begreberne om governmentality og selvteknologi. Det centrale i Foucaults magtbegreb er det relationelle og det produktive element. Gennem magtrelationer produceres subjektivitet, det vil sige, at de legitime subjektpositioner, som 
individer kan indtage, afgrænses fra de illegitime igennem de magtrelationer, som individerne indgår i. I denne afgrænsning er diskursen central, idet det er den, der bruges til artikulering af det legitimes grænser (Foucault 1982). Når det kommer til individernes forhold til staten, introducerer Foucault begrebet governmentality, hvormed han begrebsliggør de pastorale magtformer, som er kendetegnende for moderne staters styringsformer. Det handler om at styre både gennem viden og gennem omsorg. At styre gennem viden handler om, at al vidensproduktion, med tilhørende diskurser og kategoriseringer af verden, er forbundet til de gældende magtstrukturer, som former denne viden, der igen understøtter strukturerne. Foucault bruger i den forbindelse begrebet vidensregime. At styre gennem omsorg vil sige at tage sig af befolkninger og derigennem gøre gode liv mulige og samtidig sikre stater af god kvalitet (Foucault 2008:95-144), Sunde, raske, produktive befolkninger kræver sunde, raske, produktive individer, der påtager sig ansvaret for sig selv. Til at begribe en del af det arbejde, der ligger i at skabe disse ansvarsfulde selv, bruger Foucault begrebet selvteknologi (Foucault 2003:146). Selvteknologi er et begreb, der indfanger de måder, hvorpå vi fremkalder, skaber, vedligeholder og udvikler selvet. Dette arbejde sker på mangfoldige måder, hvoraf én af de mest centrale er gennem italesættelsen af selvet. Foucault opererer med begrebet „bekendelse“, hvor individet gennem selvfortælling samtidig skaber sit selv. Man kunne tænke, at når individet taler om sig selv, da har individet ordet og dermed magten til at definere sig selv. Det vender Foucault om og hævder, at når individet taler om sig selv, er det så at sige ordet, der har individet og dermed magten til at definere det. Ifølge det produktive magtbegreb vil man altid være nødt til at trække på de gældende vidensregimers diskurser og disses tilgængelige begreber og positioner i en selvfortælling, og derfor underlægges individet diskursen gennem bekendelsen. Samtidig er der et krav om kohærens til selvet (op.cit.), som individet holdes op på igennem bekendelsen, og dermed er bekendelse en af de mest centrale teknikker til at skabe og opretholde kohærente selv (Foucault 2002:69-70).

Nikolas Rose arbejder videre med Foucaults governmentalitybegreb i en avanceret liberalistisk kontekst. Rose taler om avanceret liberalisme som det, der kendetegner den vestlige verden i dag. Hans pointe er, at den avancerede liberalisme ikke er ensbetydende med minimerede stater. Nok forandres de, men forandringen handler ikke om, at de bliver mindre, men nærmere om, at deres måde at styre borgerne på bliver aktivistisk, idet styringen af borgerne sker gennem frihed. At styre andre gennem deres egen frihed kræver skabelsen af ansvarlige individer, der med deres frihed træffer de rigtige valg. Dette implicerer en decentral styring, der udgår fra mange steder og instanser, og det indebærer individualiserede borgere, der påtager sig opgaven med at varetage, styre og 
forbedre sig selv (Rose 1999:xxii-iii). ${ }^{5}$ I denne artikel vil sundhedsplejerskernes og pædagogernes praksis blive forstået som eksempler på steder, hvorfra den aktive stats decentrale styring udspringer.

Ifølge Ove Kaj Pedersen er flere elementer kendetegnende for udviklingen fra velfærdsstat til konkurrencestat. Helt overordnet er, at staterne i højere grad end tidligere nu konkurrerer med hinanden. Dette er muliggjort af flere årsager, blandt andet at de nationale og regionale markeder er blevet åbnet op, og nationalstaterne derfor har mistet nogle af de protektionistiske redskaber, de tidligere har haft (Pedersen 2011:72).

Pedersen fremhæver tre opfattelser, der særligt forandres i konkurrencestaten: demokrati, fællesskab og individ. I velfærdsstaten handlede demokrati om borgernes demokratiske deltagelse (op.cit.183-84), men i konkurrencestaten er dette blevet reduceret til valgdeltagelse (op.cit.197-98), ligesom fællesskabet heller ikke er det demokratiske, men karakteriseret af et arbejdsfællesskab (op.cit.170, 188). Opfattelsen af individet er tillige forandret: Individet er gået fra at være en værdi i sig selv, en uerstattelighed (op.cit.15, 180), til at individets værdi i konkurrencestaten bliver vurderet ud fra dets præstationer, indsats og vilje. Individet er blevet en ophobning af interesser, som skal forvaltes på bedst mulig vis for at få succes på arbejdsmarkedet (op.cit.190-91). Denne forandring implicerer nogle ganske nye krav til personligheden, som Pedersen kalder for den opportunistiske personlighed (op.cit.190) - det er den, der belønnes i konkurrencestaten.

Svend Brinkmann er optaget af de psykologiske implikationer af konkurrencestaten. I hans analyse af kravene til individet i konkurrencestaten bruger han ordet „terapeut“" som billede. Individet skal være empatisk, evne dialog, og det skal både hvile i og lede sit selv (Brinkmann 2008b:200). Han iagttager to samtidige diskurser, en „blød“ diskurs, der stiller krav om selvudvikling, positivitet, værdsættelse, anerkendelse, kreativitet og innovation, og en ,hård“ diskurs, der handler om test, evidens og evalueringskultur (op.cit.202-03). Disse kan synes modsatrettede, men det er hans pointe, at de fordrer hinanden (Brinkmann 2008a:169). Det konkurrencestatslige idealmenneske, som beskrives i de to forfatterskaber, rummer således konkurrencementalitet og egennyttighed såvel som empati og selvindsigt (Brinkmann 2008b:200; Pedersen 2011:190).

På baggrund af ovenstående vil jeg afslutte den teoretiske del med at gentage spørgsmålet: Hvis konkurrencestaten er en realitet, hvordan må man da forvente at kunne se den i praksis? Hertil vil jeg svare, at jeg på baggrund af den præsenterede teori særligt vil have tre fokuspunkter: kravene til selvet, den kompetitive forvaltning af interesser og potentialer samt arbejdsmarkeds orientering. Det første fokuspunkt, kravene til selvet, omhandler skabelsen og 
opretholdelsen af et ansvarligt selv. Det andet fokuspunkt om den kompetitive forvaltning af interesser og potentiale omhandler Pedersens pointe om, at individet i konkurrencestaten er gået fra at være en uerstattelighed til at få værdi gennem sine faktiske meritter, hvilket indskriver individet i en kontinuerlig konkurrence med de andre individer og med sig selv. Pedersens pointe om, at fællesskabet i konkurrencestaten gennemsyres af arbejdsmarkedsorientering, er analysens tredje fokuspunkt.

\section{Konkurrencestat i praksis?}

Velfærdsstatens tilgang til de 0-6-årige børn er interessant, fordi de små børn på den ene side er statens fremtid, men på den anden side er de endnu så små, at implikationerne af staternes tiltagende konkurrence (måske) endnu ikke viser sig som krav til dem. Analysen indledes med en kort historisk beskrivelse af de dominerende tilgange til og syn på barnet, som har præget det pædagogiske felt de seneste ca. 50 år. Dernæst følger analysen, som er inddelt efter de ovenfor beskrevne fokuspunkter.

Det pædagogiske område i Danmark er præget af pluralisme, men der er dog retninger, som har haft mere gennemslagskraft end andre. Fra 1960'erne og frem var særligt den strukturerede marxistiske pædagogik og den kritisk frigørende pædagogik dominerende. Disse retninger havde beslægtet marxistisk/socialistisk idégrundlag, men var i praksis meget forskellige. Den strukturerede pædagogik var optaget af, at børneopdragelse var et samfundsanliggende, og man var i den forbindelse inspireret af Sovjetunionen og Kina. Som navnet antyder, var dagligdagen i vuggestuer og børnehaver med denne pædagogiske tilgang meget struktureret, ofte i form af emnearbejde om formiddagen, fri leg derefter og så børnemøder om eftermiddagen (Bayer 2015:133-37). Den kritiske pædagogik havde et helt andet fokus; her var det individets frisættelse, der var i centrum. Man kritiserede den strukturerede pædagogik for, at strukturen var for dominerende, og at børnene som subjekter gled i baggrunden og dermed blev reduceret til objekter. Den kritiske pædagogik var således optaget af barnets erfaring, og det var inden for denne tradition, at begrebet selvforvaltning blev udviklet og fik stor gennemslagskraft i slutningen af 1980'erne og frem (Bayer 2015:138-40).

Midt i 1990'erne sker et brud inden for den danske pædagogiske tradition ved fremkomsten af ,kompetencepædagogikken“. Centralt i forandringen står, at man begynder at opfatte barnet som kompetent, som et individ, der allerede fra fødslen er i stand til mange ting, og som har en rettethed mod verden, som gør det kompetent til at udvikle sig (Sommer 1996:159). I en dansk sammenhæng er Jesper Juul og Dion Sommer centrale stemmer, når det gælder dette nye perspektiv 
på barnet. Juul med bogen Dit kompetente Barn (1995), der fik stor udbredelse, både $\mathrm{i}$ den pædagogiske verden og som håndbog for forældre, og Sommer med bogen Barndomspsykologi (1996), hvor han, på baggrund af Daniel Sterns nye psykologiske teorier om spædbarnets selv, præsenterer, hvad han kalder ,,kompetencebarnet". Dette nye perspektiv på barnet skaber en større interesse for barnet som individ og dets selvudvikling. Samtidig begynder man at opfatte barnet som et læringssubjekt - en human ressource, hvis læring begynder, når det fødes, og hvor det pædagogiske ansvar i daginstitutionerne er at stimulere barnets læring, således at det er bedst muligt forberedt på skolelivet (Hamre 2015:178-92). I 2004 cementeres dette gennem en ændring af lov om social service, som pålægger alle daginstitutioner at udarbejde læreplaner for arbejdet med børnene. Læreplanerne skal omhandle seks overordnede temaer, og i lovforslaget til ændringen stod blandt andet: „Læringsmålene er fælles overordnede mål for, hvilke kompetencer den pædagogiske læringsproces i dagtilbuddet skal lede frem imod“" (Socialministeriet 2003).

Opfattelsen af barnet som en økonomisk ressource er et perspektiv, der vinder frem, hvilket nedsættelsen af Task Force om Fremtidens Dagtilbud vidner om. Denne task force blev nedsat i 2011 af den daværende Venstre-ledede regering, men fortsatte sit arbejde efter regeringsskiftet og udkom med tre rapporter i 2012. Her er barnet ikke omtalt som en uerstattelighed med værdi i sig selv, som Ove Kaj Pedersen taler om (Pedersen 2011:180), men derimod er de økonomiske termer fremherskende. Der tales om konkurrenceevne, økonomistyring og investeringer (Task Force om Fremtidens Dagtilbud 2012b). Som der står i forordet til en af rapporterne:

En krone investeret i dagtilbud af høj kvalitet giver et langt større afkast end investeringer senere i livsforløbet. Det gælder for det enkelte barn og for samfundet som helhed (Task Force om Fremtidens Dagtilbud 2012a:5).

Inden for de pædagogiske metoders område er der samtidig sket en markedsliggørelse, som viser sig, ved at der er opstået et marked for programmer, der skal bruges til udvikling af børn. Det gælder særligt udviklingen af deres sociale kompetencer. Programmerne sælges som produkter, interesserede institutioner kan købe, hvortil der ofte også udbydes kurser for personalet i tilkøb. En kortlægning af alle børnehaver i Aalborg Kommune viser, at 63 procent benytter et af de ovennævnte programmer $i$ arbejdet med børnenes sociale kompetencer (Pedersen 2014:1). Det gælder blandt andet de to institutioner, hvis praksis indgår som en del af analysens empiri.

Således kan man iagttage, at der inden for det pædagogiske felt er sket en orientering mod børnenes selv og deres kompetencer, ligesom der er kommet et 
fokus på børn som læringssubjekter. Med dette afsæt skal der ses nærmere på analysens første del: selvarbejde i 0-6-årsalderen.

\section{Selvarbejde i 0-6-årsalderen}

Arbejdet med de helt små børns selv kommer i sundhedsplejen til udtryk på flere forskellige måder, der alle har det til fælles, at de bygger på en individualiseret tilgang til barnet, hvor man opfatter barnet som et kompetent individ, der skal have plads til at udfolde sig. Forældrene skal lære barnet at kende, og man opfordrer til en behovsorienteret pasning af barnet. De behov, barnet giver udtryk for at have, skal forældrene lære at aflæse og dernæst efterkomme. Dette ses både i praksis og i Sundhedsstyrelsens fag- og håndbøger om børn, ${ }^{6}$ og det kan synes selvfølgeligt for en nutidig læser, men har bestemt ikke altid præget sundhedsplejen. Sundhedsplejen som institution blev oprettet i 1937, og dengang var dogmet „ro, regelmæssighed og renlighed“", hvilket betød, at disciplinering og regulering af børnene stod centralt snarere end det at give plads til børnenes individualitet. Børnenes individualitet blev tværtimod opfattet som en manipulerende kilde til, at forældrene kunne miste grebet, hvis de gav efter for den, eksempelvis ved at lade barnet die uden for de fastlagte tidspunkter (Buus 2001:391-96; Monrad 1936:38-40). Hvor barnets individualitet historisk har været opfattet som noget, der skulle tøjles og formes, er det i dag en af forældrenes væsentligste opgaver at give den plads. Det ses i mit empiriske materiale særligt på to måder: gennem en behovsorienteret tilgang til barnet og gennem verbalisering af barnets indre.

Med behovsorienteret tilgang til barnet menes, at man særligt i barnets første halve leveår har fokus på at imødekomme dets signaler og behov. Det betyder ikke, at man slet ikke regulerer barnet eller sætter grænser for det, men udgangspunktet er, at man skal imødekomme barnets signaler og behov, når det eksempelvis gælder amning, kropskontakt og søvn (Pedersen 2015:199-213). Denne behovsorientering er ikke kun rettet mod fysiologiske behov, men også mod basal tryghed og psykisk velbefindende. Dette udtrykkes fint af en sundhedsplejerske, der rådgiver en ung mor til et 12 dage gammelt barn, som ifølge moren efterspørger megen kropskontakt og amning:

Ved du hvad? Så har han bare så meget brug for dig, lige såvel som du har brug for ham. Han kan ikke få nok kropskontakt, for han skal virkelig mærke dig. Så giv ham alt det, du kan. For han bliver mere tryg ved det hele. Det, du giver ham nu her ved at reagere på, at han gerne vil være ved dig, det skal han leve af hele sit liv - så at han får den dér: 'Mor hun reagerer på, at jeg kalder.' Så bliver han tryg ved tilværelsen, han har lyst til at opleve tilværelsen. Det samme når du snakker med ham og kigger ham i øjnene, så giver du ham lysten til at udvikle sig. 
Når det gælder verbalisering af børnenes indre, er det klart, at det ikke er børnene selv, der taler. Det er derimod centralt i sundhedsplejerskernes vejledning af forældrene, at de opfordrer dem til at sætte ord på de følelser, de tror, barnet har. Nedenfor ses to eksempler. Det første er et råd fra en sundhedsplejerske til en mor, der har en syv måneder gammel dreng, der bliver meget vred, når han spiser:

Men hvis du hjælper ham med at sige: 'Det går nok, jeg kan godt se, at du ikke vil have mere', hvis du ligesom hjælper ham med rammerne, bliver det meget nemmere for ham at rumme, at det er okay. Og så kan du sige: 'Jeg ser, at du ikke vil have mere, det er okay', og så kan du handle og sige: 'Nu tager jeg dig ned på gulvet', eller hvad I nu skal lave. For det er måden at lære at rumme det for ham, og så kan det være, at han kan lære at takle det bedre og bedre.

Ved at sætte ord på, først hvordan barnet har det, og siden hvad der skal ske, er det tanken både at få verbaliseret barnets følelser og at skabe forudsigelighed. Det samme ses i det næste eksempel, som omhandler en 14 måneder gammel dreng, der under sundhedsplejerskens besøg er meget urolig, og hvor sundhedsplejersken lige præcis gerne vil have flere ord og mere forudsigelighed ind i hans hverdag:

Så sig til ham ... giv ham nogle ord: 'Jeg kan godt høre, at du er rigtig vred over det her.' Hjælp ham til at acceptere den her følelse af vrede. Det kan man gøre ved at sige: 'Jeg kan høre, du er gal og vred, og du er sur, og du er rasende', og hvad man nu kan finde af ord, 'men du må ikke, du må se på det dér i stedet'. For så er I med til at beskrive den der følelse, han har, og det gør det lettere for ham at være $\mathrm{i}$ den der vrede.

Foucault taler om bekendelse som en selvteknologi. Hvis man skal bruge det begreb i denne sammenhæng, må man, grundet børnenes alder og sproglige udvikling, se det som bekendelse pr. stedfortræder - en tidlig introduktion til den praksis, det er at sætte ord på følelser og styre dem derigennem.

Hvor bekendelsen som selvteknologi i ovenstående kun er indirekte, er den i følgende situation fra en af børnehaverne direkte og tydeligt til stede. Det drejer sig om pigen Marie på fem år. Hun har et kompliceret forhold til mad, da der er rigtig meget mad, hun ikke bryder sig om. Hun bliver i forbindelse med frokosten denne dag utrolig ked af det, ikke kun over maden, men over i det hele taget at være i børnehaven. Hun bliver inde, da de andre skal på legepladsen, og da der er ro på stuen, sætter pædagogen Birthe sig med Marie for at tale med hende om, hvad det er, der gør hende så ked af det:

Birthe (B) har et stykke papir og skriver øverst: Hvad skal der til, for at Marie (M) bliver glad for at gå i børnehave igen? Birthe læser det op.

M: Jeg tænker... 
B: Det er måske også svært. Måske er det lettere at tænke over, hvad det er du er ked af, når du skal her hen om morgenen?

M: Det føles, som om alle børnene driller mig.

B: Det føles, som om alle børnene driller dig. Det er da heller ikke rart, at det føles sådan. Det skriver jeg ned.

M: Det er også, fordi jeg kun har tre venner.

B: Du har kun tre venner. Se, vi skriver her dine venner, hvem er det?

Herefter følger en længere samtale om, hvem Marie godt kan lide, og hvem hun er venner med. Det viser sig ved nærmere gennemgang at være en del.

B: Det var mange. Prøv at se på de børn, vi har skrevet på her, som du synes, er dine venner, det er faktisk mange, hva'?

$\mathrm{M}$ : Ja, jeg har faktisk mange venner.

B: Hvad så med det, du ikke kan lide hernede? Det med, at der er nogen, der driller, hvem er det?

M: Det ved jeg ikke.

B: Du sagde, at alle børnene drillede. Kan du komme i tanke om, hvem det er?

M: Mest Thomas.

B: Okay, så vi skal lige holde lidt øje med, hvordan det er med dig og Thomas.

M: Og også Benjamin og lidt Anna.

B: Det skal jeg nok være lidt opmærksom på, Marie. Er der noget andet, som du ikke så godt kan lide herhenne?

M: Der er det med maden.

Marie og Birthe taler herefter videre om, hvad de kan gøre ved Maries ubehag ved maden.

Der er ingen tvivl om, at Marie som individ bliver taget alvorligt. Hun sætter ord på sine følelser og oplevelser, og Birthe lytter og spørger ind. Birthe spejler og korrigerer Maries ord og genfortolker derigennem Maries oplevelse af at være venneløs i en børnehave, hvor alle driller - og til, gennem Maries egne ord, at anskueliggøre virkeligheden på en ny måde, hvor børnehaven, de andre børn og Marie selv står i et bedre lys. Når man læser samtalen mellem Marie og Birthe, emmer den af omsorg og nærvær. Omsorg handler dog ikke kun om at tage sig af; den handler også om at lede den, der ydes omsorg, i en bestemt retning (Foucault 2008:136-38). I eksemplet trænes Marie i at sætte ord på sig selv, reflektere over sig selv og i at arbejde med sig selv ved at korrigere sit selvbillede. Denne træning er fremtrædende i eksemplet med Marie og Birthe, men jeg vil mene, at selve installationen af det selvrefleksive blik går igen i rigtig mange dele af den pædagogiske praksis.

Det gælder fx metoden „Den gode stol“, som går ud på, at et barn fra gruppen sættes på en stol, hvoromkring de andre børn sidder i rundkreds. De skal på skift sige noget positivt om barnet i midten. Metoden er ganske udbredt, både på daginstitutionsområdet og i skolerne. I det følgende eksempel er det Anton på tre år, der er kommet i den gode stol. Stemmerne i uddraget tilhører Bettina, der 
er pædagogstuderende og ansvarlig for aktiviteten, og Mari på fire år, Vilde på tre år og Mikaela på tre år:

10 børn i alderen 21/2-4 år sidder i rundkreds på en madras med Anton i midten. Bettina spørger, om børnene kan huske, hvad der skal ske. Det er der flere, der kan. Mari er den første, der får ordet:

Mari: Anton er god til at lege med mig.

Bettina: Han er god til at lege med dig. Andre der vil sige noget? Mikaela?

Mikaela: Anton er god til at lege med pinde.

Bettina: Med pinde? Ja, Vilde?

Vilde: Anton er god til at lege med pinde og med mudder.

Mari: Mig mig mig.

Bettina: Mari?

Mari: Øhh, øhh ...

Bettina: Vil du sige noget, Mari?

Mari: Ja, Anton er god til at lege med klodser.

Bettina: Ja, han er god til at lege med klodser, men noget af det, som jeg synes, Anton er god til, det er at se, hvis der er andre, der er kede af det. Det er Anton rigtig god til.

Situationen rummer mange elementer, eksempelvis er det et sideløbende tema at få disse ret små børn til at sidde stille og ikke at tale i munden på hinanden og at styre de særligt talende eller urolige børn. Formålet med metoden er at skabe sammenhold og at minde børnene om de andre børns positive egenskaber og evner. Selv om ovenstående opremsning af pinde, mudder og klodser, som Anton er god til at lege med, kan virke langt fra noget, der handler om selvarbejde, vil jeg mene, at metoden installerer bevidsthed hos børnene om, at de hver især har personligheder med særlige kendetegn, som man kan iagttage, beskrive og reflektere over. Bettinas kommentar om, at Anton er god til at se, når andre børn er kede af det, vidner samtidig om, at Bettina forsøger at styre fokus fra pinde og mudder til Antons mere personlige kvaliteter - en dybde i metoden, som disse børn endnu ikke har fanget.

Et Fri for Mobberi-børnemøde i en vuggestue indeholdt både selvrefleksive elementer og en træning $i$ at tolke og sætte ord på følelser. Jeg deltog i et børnemøde med en pædagog og tre toårige børn, der sad i rundkreds og talte om følelser ud fra billeder på en planche, hvor der var fine ansigter med forskellige ansigtsudtryk. Samtalen handlede både om, hvilke følelser børnene kunne se udtrykt på billederne, og om, hvordan de selv havde det, når de så sådan ud - hvad der kunne gøre dem glade, forskrækkede eller kede af det. Man kan sige, at dette møde både handlede om bevidsthed om selvet, om følelser og om „den anden“.

På børnemøderne i børnehavegrupperne var der på samme måde fokus på egne og andres følelser og på at få sat ord på dem. Det var også en integreret del af 
løsningen af konflikter mellem børnene, at pædagogerne opfordrede børnene til enten at tolke et andet barns følelser, fx: „Så du, hvordan Harald så ud i ansigtet, da du tog bolden fra ham?“, at sætte ord på egne følelser eller at lytte til den andens ord:

Jeg sidder på stuen med flere børn, der laver perlehalskæder. Der opstår en konflikt mellem Marius og Thomas. Marius græder højt, og Helene (pædagog) kommer ind på stuen, formentlig hidkaldt af lyden. Begge børn fortæller i munden på hinanden. Helene siger: 'Nej, nej, nej, nu skal I tie stille begge to, og så ved I godt, at her gør vi det sådan, at først fortæller den ene og så den anden. Så Thomas, nu fortæller du, hvad der skete, og så lytter du Marius.' Thomas fortæller, og Marius lytter, og dernæst er det Marius' tur til at fortælle. Konflikten bliver løst gennem denne samtale.

Eksemplet viser, hvordan det står centralt i konflikthåndteringen at tale om tingene - mindre centralt er det at fă placeret skyld (dette er dog afhængigt af, hvad konflikten handler om, da der i mere alvorlige tilfælde også placeres skyld). Pædagogen optræder ikke som dømmende autoritet med magt til at afgøre, hvem af børnene der har ret, men hun er facilitator af en konfliktløsende samtale. Børnene tilskyndes i sådanne følelsesladede intense situationer til at kunne tøjle deres følelser så meget, at de er i stand til at lytte til den andens ord og til at kunne formulere deres egne følelser.

Der bliver i daginstitutionerne også arbejdet med at lære børnene at mærke sig selv med henblik på at gøre dem i stand til at styre og regulere sig selv, fx gennem yoga og massage. Efter at have deltaget $\mathrm{i}$ børneyoga i den ene børnehave talte jeg om det med den pædagog, der havde stået for det. Hun sagde: „Et af målene med at lave børneyoga er jo at øve børnene i at mærke sig selv og deres grænser - mærke deres kroppe og øve sig i at finde ro i kroppene.“ En måde, børn skal styre sig selv på, er ved at kunne tøjle deres vildskab. I løbet af en børnehavedag vil det forekomme mange gange, at børn får at vide, at de skal lade være med at løbe indenfor, at de råber for højt, at de skal sidde stille, eller at de ikke må hoppe i sofaerne. At blive bedt om at tone sit energiniveau ned er en meget basal børneerfaring (se også Gulløv 2012). Børnene er på dette område i høj grad er udsat for ydre styring, idet de får mange påbud og henstillinger, men ofte rummer disse også appeller til børnene om selv at skulle kunne mærke i situationen, hvornår det er for meget, for larmende eller for voldsomt. I den ene børnehave havde de en tumlekælder, som var et knap $100 \mathrm{~m}^{2}$ stort rum med plads til vildskab, og det var ofte der, vildskaben blev dirigeret hen, når den blev sanktioneret oppe i børnehaven. En dag efter et børnemøde med massage i kælderen vælger pædagogen Helene at slutte af med en fangeleg. En del af Fri for Mobberi-konceptet er, at der er tilknyttet en bamse, der hedder Bamseven: 
Efter massagen siger Helene: 'Så slutter vi af med fangeleg. Bamseven ser, om han kan fange jer.' Alle børnene hviner højt og styrter til alle sider. Helene løber rundt og fanger børnene med bamsen, og børnene råber begejstret. Fangelegen fortsætter højlydt. På et tidspunkt stopper Helene op og siger: 'Stop! Kan I ikke se, at Bamseven holder sig for ørerne? Han får helt ondt i ørerne. Det er alt for højt. Kan I se, at Bamseven får ondt i ørerne, når I råber så højt?’ Alle børnene styrter hen til Helene og bamsen og krammer den. Bagefter går alle op i børnehaven.

Under massagen var nogle af børnene ret urolige, og Helene fortalte bagefter, at tiltaget med at slutte af med fangeleg var en idé, hun fik, fordi hun syntes, de skulle have lov til at „krudte af". På trods af den intention viser eksemplet, at kravene om at kunne tøjle sig selv og styre sig er meget gennemgående, selv når der er inviteret til vildskab. Antropolog og barndomsforsker Eva Gulløv, der sammen med Laura Gilliam er forfatter til bogen Civiliserede institutioner - om idealer og distinktioner i opdragelse (2012), viser, hvordan kravene til børn er, at de skal balancere mellem ro og vildskab samt orden og kaos på en måde, hvor de hverken skal være for vilde eller for stille. Selv om de fleste sanktioner går i retning af, at børnene skal dæmpe sig, både i mit materiale og hos Gulløv, bliver det også problematiseret, hvis et barn er meget stille og slet ikke vild (Gulløv 2012:81-82). Gulløv har dertil den pointe, at det er centralt i vor tids civilisering af børn, at de selv fra situation til situation skal kunne mestre afkodningen af, hvilken adfærd der er acceptabel. Tidligere tiders klare autoritære rammer er der ikke, og nu er det op til børnene selv at fornemme sig frem (op.cit.89) - et ønske, Helene også giver udtryk for i eksemplet, når hun spørger, om børnene ikke kan se, at Bamseven holder sig for ørerne, fordi de råber for højt. Gilliam og Gulløv pointerer, at det er vor samtids fravær af tydelige autoriteter og klare rammer, der nu i højere grad end tidligere skærper kravene til børnene om at kunne afkode sociale situationer og tilpasse sig selv til dem (Gilliam \& Gulløv 2012:57).

Hvis man på baggrund af min empiri og også Gilliam og Gulløvs pointer skal opsummere på velfærdsstatens krav til de 0-6-åriges selvarbejde, er billedet af den afbalancerede, lyttende, empatiske og dialogorienterede terapeut, som Brinkmann bruger om konkurrencestatens idealmenneske, ikke fjernt (Brinkmann 2008b: 200). Vi ser det i form af den træning, som børnene helt fra små og på varierende måder $i$ henholdsvis sundhedsplejen og daginstitutionerne, gennemgår. Træningen består i at få dem til at sætte ord på følelser, til at lytte til andre og til at kunne mærke og styre sig selv. Det sker gennem det, man med Foucaults begreb vil kalde selvteknologier. Med inddragelse af Rose giver det mening at tolke dette mangfoldige selvarbejde som den decentrale stats arbejde med at styrke børnenes evner til situationsbestemt selvstyring og derigennem, på sigt, til frihed. I det følgende vil der blive se nærmere på, hvorvidt kravene til børnene også rummer et kompetitivt element. 


\section{Den indirekte konkurrence}

Brinkmann skriver om konkurrencestatens krav om udvikling af potentiale:

Som subjektanspores man derfor tilatse sigselv som permanentudviklingspotentiale, som det er muligt at erkende og 'arbejde med' i markedsegnede retninger. Og selv om det enkelte menneske begrebsliggøres som kompetent, selvledende og frit vælgende, er det vanskeligt at vælge netop denne begrebsliggørelse fra (Brinkmann 2008b:198-99).

For forældre, som modtager sundhedspleje, betyder det, at man ikke kun skal arbejde med sig selv og sit eget udviklingspotentiale. Som ansvarlige forældre skal man formå at få mest muligt ud af barnets potentiale i bred forstand. Det gælder den fysiske og den psykiske sundhed, og det gælder den mentale, den sproglige og ikke mindst den motoriske udvikling. Barnets motoriske udvikling er et område, hvor forældrene ved hjælp af øvelser kan gøre en forskel, og hvor sundhedsplejerskerne ofte rådgiver om hvordan. Der ligger i dette et implicit udviklingsfokus, hvor man fremmer et syn på barnet som et subjekt, der skal arbejdes med for at få mest muligt ud af dets potentiale. Dermed fremmes tillige et syn på den ansvarlige forælder som én, der påtager sig denne udviklingsopgave. Dette står i kontrast til den tidlige sundhedspleje. Ved sundhedsplejeinstitutionens oprettelse var rådet til forældre at lade børnene ligge så meget som muligt for sig selv, og den ansvarlige forælder formåede ikke at overstimulere barnet (Buus 2001:43240). I dette syn på udvikling af potentiale, som gennemsyrer sundhedsplejen i dag, ligger et implicit, men sjældent direkte udtalt, konkurrenceelement.

Konkurrenceelementet er på samme måde kun indirekte til stede i min empiri fra daginstitutionerne. Det virker, som om det at få fællesskabet til at fungere og det at forebygge og løse konflikter er mere centralt end at tilskynde børnene til at konkurrere. Der bruges, som vi har set i forrige afsnit, meget energi på børnene som individer, men det er især på de områder, der handler om at kunne fungere godt i fællesskabet, mens der ikke er eksplicit fokus på at fremme børnenes præstationer. Helt fraværende er brugen af konkurrencevokabular. Børnene tilskyndes ikke til at konkurrere med hinanden, til at hævde sig over for hinanden eller til at udnytte egne fortrin på fordelagtig opportunistisk vis. Man ser ikke børn fremhævet som vindere, individuelle sejre hyldes ikke, ligesom individuelle præstationer ikke fremhæves.

Når jeg alligevel vil argumentere for, at der ses et indirekte konkurrenceelement, er det gennem den konstante spejling af sig selv i sammenligning med andre, som er en del af den træning i selvrefleksivitet, som fylder så meget i institutionerne (jævnfør forrige afsnit om selvarbejde). Evaluering er derigennem et grundvilkår, hvori der både indgår et konkurrenceelement og et element af social kontrol, idet 
ens adfærd og færden hele tiden kan blive genstand for diskussion og refleksion, hvad enten det sker i mindre kontekster med få børn og en voksen, eller det sker i plenum til børnemøder.

Pedersen påpeger, at konkurrencestaten kræver opportunistiske personligheder (Pedersen 2011:190), og denne pointe fører til spørgsmålet om, hvorvidt dette viser sig som et krav til børnene om kompetitiv forvaltning af deres potentialer og interesser. Det gør det ikke særlig tydeligt, men det er dog heller ikke helt fraværende. Man ser det ved den ansvarliggørende udviklingsfordring, der ligger i sundhedsplejerskernes fokus på at få forældrene til at arbejde målrettet med børnenes potentialer, og man ser det ved det mangfoldige og vedvarende arbejde med styrkelse af vuggestue- og børnehavebørns bevidsthed om sig selv i relation til de andre.

\section{Arbejdsmarkedsorientering for de 0-6-årige?}

Pedersen pointerer, at fællesskabet i konkurrencestaten er gået fra at være et demokratisk fællesskab til i stedet at være et fællesskab, der bygger på arbejdsmarkedet ( Pedersen 2011:170,188). Kan man forestille sig, at dette er tydeligt $i$ professionernes arbejde med børn, der er under seks år gamle?

Det er det ikke i sundhedsplejen, hvis man med arbejdsmarkedsorientering tænker på en orientering mod børnenes fremtidige arbejdsmarkedsdeltagelse, men der ses derimod en anden arbejdsmarkedsorientering, der handler om forældrene. Sundhedsplejerskerne rådgiver forældrene om, hvordan de kan lette deres egen arbejdsmarkedsdeltagelse gennem det at forberede børnenepå udepasning(Pedersen 2013, 2015:199-214; Sundhedsstyrelsen 2011a:16-17, 2011b:105). Forældrenes arbejdsmarkedsdeltagelse indgår som en præmis for sundhedsplejerskens rådgivning, hvilket den ikke altid har gjort (Buus 2001). Den arbejdsmarkedsorientering, man ser i sundhedsplejen, er således møntet på forældrenes og ikke børnenes arbejdsmarkedsdeltagelse og må dermed siges at være indirekte.

På daginstitutionsområdet forholder det sig lidt anderledes, idet man både ser arbejdsmarkedsorienteringen som en præmis for selve området og mere direkte i arbejdet med børnene. Faciliteringen af forældrenes arbejdsmarkedsdeltagelse må være en meget væsentlig årsag til, at man investerer i uddannelse af pædagoger og drift af institutioner, og at man yder tilskud til, at børnene kan gå i vuggestue og børnehave. Derudover ses også, hvad man måske mere retvisende kunne kalde en „fremtidsorientering“, i arbejdet med børnene. Indførelsen af de lovpligtige læreplaner vidner om en form for fremtidsorientering i synet på barnet. Barnet er ikke blot et barn på den alder, det har her og nu, det er også et kommende skolebarn. I praksis ses denne fremtidsorientering ved, at børnehaverne har skolegrupper for 
de børn, som skal begynde i skole efter næste sommerferie. Gennemgående er, at der systematisk arbejdes med at gøre dem parate dertil. Det gælder begyndende skolefærdigheder som tal- og bogstavgenkendelse, læren om månederne og årstiderne etc., og det gælder også deres sociale kompetencer. I den ene af de to undersøgte børnehaver havde de eksempelvis særligt fokus på denne del med et intensivt Fri for Mobberi-forløb for skolegruppen i forårsmånederne.

Arbejdsmarkedet er således en præmis for daginstitutionerne, og derudover ses den fremtidsorienterede opfattelse af barnet - dets fremtidige deltagelse på arbejdsmarkedet - igennem klargøring af barnet til uddannelsessystemet. Dermed opfattes barnet som et læringssubjekt, der ikke blot er, men er på vej.

Fælles for sundhedsplejen og for daginstitutionsområdet er, at kravene fra arbejdsmarkedet om forældrenes deltagelse er en præmis, som er formende for deres virke og, for daginstitutionsområdet, også for dets eksistens. Gældende for daginstitutionsområdet er tillige, at det her er mere tydeligt, at børnene bliver opfattet som kommende arbejdskraft.

\section{Konklusion}

Artiklens hovedspørgsmål var: Hvis konkurrencestaten er en realitet, hvilke krav stiller den da til de 0-6-årige børn? Dette spørgsmål blev operationaliseret til tre fokuspunkter i analysen: kravene til selvet, den kompetitive forvaltning af interesser og potentiale samt arbejdsmarkedsorientering. I konklusionen vil jeg følge analysen af disse fokuspunkter op med tre spørgsmål: Hvad har vi set? Er dette noget nyt? Og sidst: Er konkurrencestatsbegrebet relevant for forståelsen af velfærdsstatens arbejde med de 0-6-årige?

Vi har set de tre fokuspunkter gøre sig gældende på varierende måder og $\mathrm{i}$ varierende omfang. Mest tydelige og omfangsrige var kravene til børnenes selvarbejde. De indebærer en kontinuerlig træning i selvbevidsthed, selvrefleksion og selvkontrol. Derudover er der forventninger til børnene om at skulle verbalisere deres følelser, om at kunne forestå konfliktløsning, udvise fleksibilitet samt have situationsfornemmelse. I forhold til det kompetitive element i arbejdet med børnene var det mere implicit end eksplicit til stede. Det ses gennem den store bevidsthed, som børnene qua selvarbejdet får på sig selv og på hinanden i daginstitutionerne, og det ses i sundhedsplejerskernes indskærpelse til forældrene om at arbejde med at få mest muligt ud af børnenes potentiale. Arbejdsmarkedsorient eringen var både til stede som en indirekte formning af den sundhedsplejefaglige praksis og som en præmis for selve daginstitutionsområdet. Derudover sås $\mathrm{i}$ arbejdet med især de store børnehavebørn en fremtidsorientering i retning af uddannelsessystemet og dermed arbejdsmarkedet. 
Er dette noget nyt? Både-og. Hvis man ser på de seneste 50 års pædagogisk tradition i Danmark, er der elementer i den nutidige praksis, der både er meget forskellige fra og lig denne. Der er træk, der minder om både den strukturerede og den kritiske pædagogik, om end de kommer til syne på nye måder. Med læreplanernes indførelse i 2004 har man styrket læringsaspektet af den pædagogiske praksis, og man har pointeret, at barnets tidlige læring er et samfundsanliggende. Som en konsekvens er børnemøder med et voksenstyret læringsindhold - gennem de udbredte programmer - blevet en del af mange daginstitutioners dagligdag. I dette ses træk af den strukturerede pædagogik, som netop havde fokus på børnenes læring som et samfundsanliggende og havde voksenstyrede børnemøder på programmet. ${ }^{7}$ Den store forskel er selvfølgelig, at den læring, der nu sker, ikke handler om at bevidstgøre børnene om det kapitalistiske samfunds undertrykkelse (Bayer 2015:136), men nærmere om at forberede dem på at kunne indgå i det kapitalistiske samfund. Elementer fra den kritiske pædagogik ses særligt ved det store fokus på og interesse for barnet som individ og det selvarbejde, der deraf følger. Forskellene er dog, at dette ikke i dag er forbundet med frigørelse fra autoriteter - tværtimod har det i højere grad karakter af tilpasningsarbejde. Derudover er selvarbejde i dag ikke blot en mulighed, barnet gives, selvarbejde er derimod blevet et krav. Selv om der således ses en arv fra både den strukturerede og den kritiske pædagogik i nutidig praksis, er det relevant i en konkurrencestatslig sammenhæng at bemærke, at disse retningers tidligere samfundskritiske brod ikke er en del af denne arv.

Vil jeg på den baggrund mene, at konkurrencestatsbegrebet er relevant for forståelsen af velfærdsstatens arbejde med de 0-6-årige? Der er ikke tvivl om, at der gennem sundhedsplejerskernes og pædagogernes arbejde fordres noget af børnene, som lader sig indfange af konkurrencestatsbegrebet. Det gælder særligt arbejdet med (på sigt) at skabe selvstyrede individer, der er bevidste om, reflekterer over, taler om og arbejder med sig selv. Det er børn, for hvem begge forældrenes arbejdsmarkedsdeltagelse har været et formende grundvilkår, og børn, der fra en tidlig alder bliver gjort bevidste om, at de besidder et udviklingspotentiale og kontinuerligt er på vej videre. I den forstand har konkurrencestatsbegrebet været egnet til at udfolde min empiri. Jeg vil dog indvende, at konkurrenceelementets mere indirekte end direkte tilstedeværelse i de to forskellige kontekster svækker begrebet en smule. Der er elementer af konkurrence i både sundhedsplejens ansvarliggørende udviklingsfordring til forældrene og i børnenes evige refleksioner over sig selv og hinanden, men det er ikke tydeligt til stede. Mine analyser tyder således på en vis træghed over for (eller muligvis modstand mod) at lade en ellers ret stærk konkurrencediskurs vinde indpas. Konklusionen her må være, at konkurrencestatsbegrebet er anvendeligt til at indfange dele af den 
velfærdsstatslige praksis, der er rettet mod de 0-6-årige børn, men at den del, der lige præcis handler om konkurrence, kun i mindre grad synes at gøre sig gældende for dem.

\section{Noter}

1. Feltarbejdet indgår i forskningsprojektet ESSET (Education in Social Skills and Emotional Training), Aalborg Universitet (esset.aau.dk). ESSET er bevilget af Det Frie Forskningsråd Samfund og Erhverv (FSE): 12-125308. Projektet omhandler et studie af kravene til sociale kompetencer inden for forskellige arenaer: børnehaver og indskoling, i kriminalforsorgen og på arbejdsmarked.

2. Det empiriske materiale til min ph.d. bestod af: feltobservationer af sundhedsplejens praksis (29 hjemmebesøg, fire konsultationer), interviews med sundhedsplejersker (syv interviews) og fokusgruppeinterviews med mødre i mødregrupper (syv fokusgruppeinterviews).

3. På trods af at jeg kun har tre samlede ugers feltobservationer i børnehaverne, oplevede jeg at have en del brugbar forhåndskendskab om feltet, som jeg har kunnet trække på: Ud over at have en BA i pædagogik har jeg tidligere ad flere omgange arbejdet som pædagogmedhjælper, og jeg har som forælder haft min daglige gang $\mathrm{i}$ henholdsvis vuggestue og børnehave igennem de sidste 14 år, hvor jeg også har siddet i forældrebestyrelsen i otte år. Denne fortrolighed med dagligdagen i daginstitutioner har styrket min mulighed for hurtigt at falde ind og forstå feltet.

4. „Fri for Mobberi“ er et australsk inspireret program, som er udviklet i samarbejde mellem Red Barnet og Mary Fonden. Materialet er udviklet både til daginstitutioner og indskoling. Der fokuseres på styrkelsen af børnenes sociale kompetencer, sociale relationer og på fællesskabet, således at mobning forebygges. Centralt i dette er børnemøder, men materialet rummer også massagehistorier, musik og lege.

5. En central pointe hos Rose er tillige, at denne styring gennem frihed samtidig genererer ekskluderede identiteter: over for dem der ikke formår at styre sig selv, dem sættes der ind med andet end frihed (Rose 2000).

6- Se eksempler: Sundhedsstyrelsens anbefaling om at lade barnet die efter behov (Sundhedsstyrelsen 2006:68), eller om betydningen af samvær og kontakt for udviklingen af barnets følelsesliv og selvværd (Sundhedsstyrelsen 2011a:63).

7. Det skal her nævnes, at en af de fremmeste fortalere for den strukturerede pædagogik, Stig Broström (Bayer 2015:136), også er blevet en af læreplanernes ivrige fortalere. Han argumenterer blandt andet for at forstå daginstitutionerne som en del af uddannelsessystemet (Hamre 2015:184-87).

Søgeord: konkurrencestat, daginstitution, sundhedspleje, selv-arbejde, konkurrence, arbejdsmarkedsorientering

\section{Litteratur}

Bayer, Søs

2015

Opbrud i det børnehavepædagogiske felt 1965-1985. I: S. Bayer \& J.E. Kristensen (red.): Pædagogprofessionens historie og aktualitet. Bind 2: Kald og kundskab. Side 119-69. København: U Press. 
Brinkmann, Svend

2008a Identitet - udfordringer i forbrugersamfundet. Aarhus: Klim.

2008b Selvudvikling og kompetencer i konkurrencestaten. I: S. Brinkmann \& P.

Triantafillou (red.): Psykens historier i Danmark. Side s. 189-209. Frederiksberg:

Samfundslitteratur.

Buus, Henriette

2001 Sundhedsplejeinstitutionens dannelse. København: Museum Tusculanums Forlag.

Foucault, Michel

1982 The Subject and Power. Critical Inquiry 8(4):777-95.

2002 Viljen til viden - seksualitetens historie 1. Frederiksberg: Det lille Forlag.

2008 Sikkerhed, territorium, befolkning. København: Hans Reitzels Forlag.

Fri for Mobberi

2015 www.friformobberi.dk. Besøgt 10. februar 2015.

Gilliam, Laura \& Eva Gulløv

2012 Civiliserede institutioner - om idealer og distinktioner i opdragelse. Aarhus:

Aarhus Universitetsforlag.

Gulløv, Eva

2012 Den tidlige civilisering. I: L. Gilliam \& E. Gulløv (red.): Civiliserede institutioner - om idealer og distinktioner i opdragelse. Side 63-95. Aarhus: Aarhus

Universitetsforlag.

Hamre, Bjørn

2015 Ny børnesyn. I: S. Bayer \& J.E. Kristensen (red.): Pædagogprofessionens historie og aktualitet. Bind 2: Kald og kundskab. Side 165-209. København: U Press.

Juul, Jesper

1995 Dit kompetente barn. København: Schøenberg.

Monrad, Svenn

1936 Moderens bog - det sunde barns pleje. København: Gyldendalske Boghandel, Nordisk Forlag.

Pedersen, Oline

2013 Mellem behovsorientering og regulering - diskursen om omsorg for det lille barn. Dansk pædagogisk Tidsskrift 4:59-67.

2014 Sociale kompetencer på daginstitutionsområdet i Aalborg Kommune - en kortlægning. Internt arbejdsnotat.

2015 Sundhedspleje - magt og normalisering i praksis. Frederiksberg: Frydenlund.

Pedersen, Ove Kaj

2011 Konkurrencestaten. København: Hans Reitzels Forlag.

Rose, Nikolas

1999 Governing the Soul: The Shaping of the Private Self. London: Free Association Books.

2000 Government and Control. British Journal of Criminology 40(2):321-39.

Socialministeriet

2003 Forslag til lov om ændring af lov om social service (Pædagogiske læreplaner i dagtilbud til børn). Lovforslag 2003/1 LSF 124. www.retsinformation.dk/forms/ r0710.aspx?id=90313. 
Sommer, Dion

1996 Barndomspsykologi. København: Hans Reitzels Forlag.

Sundhedsstyrelsen

2006 Håndbog i vellykket amning - anbefalinger til sundhedspersonale. København:

Komiteen for Sundhedsoplysning.

2011a Sunde børn - til forældre med børn i alderen 0-3 år. København: Komiteen for Sundhedsoplysning.

2011b Vejledning om forebyggende sundhedsydelser til børn og unge. København: Komiteen for Sundhedsoplysning.

Task Force for Fremtidens Dagtilbud

2012a Fremtidens dagtilbud - pejlemærker fra Task Force om Fremtidens Dagtilbud. Rapport 1. København: Ministeriet for Børn og Undervisning.

2012b Baggrundsrapport fra Task Force om Fremtidens Dagtilbud. Rapport 3. København: Ministeriet for Børn og Undervisning. 
